\title{
Struktur Komunitas Perifiton Pada Lamun Jenis Thalassia hemprichii dan Cymodocea rotundatta di Kawasan Pantai Sanur
}

\author{
Putu Satya Pratama a*, Dwi Budi Wiyanto a, Elok Faiqoh a \\ a Program Studi Ilmu Kelautan, Fakultas Kelautan dan Perikanan, Universitas Udayana, Kampus UNUD Bukit Jimbaran, Bali 80361, Indonesia \\ * Penulis koresponden. Tel.: +6285-792-736-564, +6281-236-034-565 \\ Alamat e-mail: fkpsatya@gmail.com
}

Diterima (received) 22 Juli 2016; disetujui (accepted) 25 April 2017; tersedia secara online (available online) 7 Mei 2017

\begin{abstract}
Seagrass has function as nursery ground, spawning ground, feeding ground and habitat for many coastal organism (benthic, fish and epiphytes). Tourism activities in Sanur beach, the habitat of seagrass, could change the water condition, it indirectly influencing the existences of seagrass plants and periphyton in Sanur beach. The aim of this study are to analyze community structure of periphyton on seagrass leaves (Thalassia hemprichii and Cymodocea rotundatta) and its relationship with water parameters in four stations at Sanur beach area that has the unique characteristics. Water parameters measured were temperature, salinity, DO (Dissolved oxyen), $\mathrm{pH}$, nitrate, phosphate, and TSS (Total Suspended Solid). Data analysis using PCA (Principal Component Analysis) to see the parameters that most influence on the abundance of periphyton. The results showed diversity index $\left(\mathrm{H}^{\prime}\right)$ of periphyton is moderate, eveness index (E) moderate to high, and dominance index $(\mathrm{C})$ is low to medium. It concluded that conditions of Sanur waters is stable but it is easily changed due to anthropogenic influences. PCA analysis showed that the parameters of the water have different effects on the abundance of periphyton at each seagrass leaves. Periphyton on Thalassia hemprichii was influenced by TSS, while Cymodocea rotundatta was influenced by phosphate, nitrate, temperature, DO, and TSS
\end{abstract}

Keywords: seagrass; periphyton; community structure; Sanur beach

\begin{abstract}
Abstrak
Lamun memiliki fungsi sebagai daerah asuhan, daerah pemijahan, tempat mencari makan, serta habitat bagi biota laut (benthos, ikan, dan epifit). Kegiatan pariwisata yang ada di kawasan pantai Sanur berpotensi menurunkan kualitas perairan, yang secara langsung dapat mempengaruhi ekosistem lamun serta perifiton. Penelitian ini dilakukan untuk melihat struktur komunitas perifiton pada lamun jenis Thalassia hemprichii dan Cymodocea rotundatta serta hubungannya dengan parameter perairan pada 4 stasiun pengamatan di kawasan pantai Sanur yang memiliki karakteristik masing-masing. Parameter perairan yang diamati adalah suhu, salinitas, DO (Dissolved Oxygen), $\mathrm{pH}$, nitrat, fosfat, serta TSS (Total Suspended Solid). Analisis data menggunakan PCA (Principal Component Analysis) untuk melihat parameter perairan yang paling berpengaruh terhadap kelimpahan. Hasil penelitian menunjukkan keanekaragaman perifiton tergolong sedang, keseragaman perifiton tergolong sedang - tinggi, dan dominansi tergolong rendah - sedang. Hal ini mencerminkan kondisi perairan di kawasan pantai Sanur dalam keadaan stabil namun cenderung berubah karena pengaruh antropogenik. Analisis PCA menunjukkan bahwa parameter perairan memberikan pengaruh yang berbeda-beda terhadap kelimpahan perifiton di masing-masing jenis lamun. Perifiton pada daun Thalassia hemprichii dipengaruhi oleh TSS, sedangkan pada daun Cymodocea rotundatta dipengaruhi oleh fosfat, nitrat, suhu, DO, dan TSS.
\end{abstract}

Kata Kunci: lamun; perifiton; struktur komunitas; kawasan pantai sanur

\section{Pendahuluan}

Kondisi lingkungan baik tanah, udara, dan air saat ini cenderung mengalami penurunan akibat semakin meningkatnya kegiatan antropogenik (Tang et al., 2014). Salah satu daerah pesisir yang memiliki kegiatan antropogenik cukup padat 
adalah kawasan pantai Sanur. Tingginya aktivitas yang ada di kawasan pantai Sanur tersebut berpotensi menyebabkan penurunan kualitas perairan dan degradasi lingkungan pantai, termasuk ekosistem di dalamnya adalah tumbuhan lamun. Padang lamun yang ada di kawasan pantai Sanur tersebar sepanjang $8 \mathrm{~km}$, dari Grand Bali Beach hingga pantai Mertasari (Dewi, 2012). Lamun dapat menjadi habitat bagi biota laut, salah satunya adalah mikroalga.

Mikroalga yang berifat epifitik atau menempel pada permukaan daun lamun dinamakan perifiton. Keberadaan perifiton di permukaan tumbuhan, dalam hal ini lamun, mempengaruhi proses yang terjadi pada tumbuhan tersebut. Orbita and Mukai (2013) menemukan bahwa lamun yang dipadati perifiton, proses fotosintesisnya menjadi terhambat. Hal ini disebabkan karena cahaya matahari yang digunakan dalam proses fotosintesis terhalangi oleh penempelan perifiton pada permukan daun lamun (Villarreal et al., 2008 ; Mabrouk et al., 2014). Selain itu, Novianti dkk., (2013) menyebutkan bahwa perifiton merupakan penyedia produktivitas perairan yang penting karena dapat melakukan proses fotosintesis yang membentuk zat organik dari zat anorganik. Berdasarkan hal tersebut, perifiton memegang peranan yang sangat penting dalam struktur trofik pada ekosistem lamun. Selain itu, perifiton juga dijadikan sebagai bioindikator pencemaran karena dapat merespon perubahan lingkungan perairan (Indrawati et al., 2010 ; Junda et al., 2013 ; Kocak and Onen, 2014 ; Fitriani dan Maulana, 2015).

Penelitian ini penting untuk dilakukan guna memperoleh gambaran awal mengenai kondisi perairan di kawasan pantai Sanur yang berpotensi dipengaruhi oleh aktivitas antropogenik yang padat di kawasan tersebut. Penggambaran kondisi perairan dengan menggunakan pendekatan struktur komunitas perifiton pada lamun belum pernah dilakukan di kawasan pantai Sanur. Hasil penelitian diharapkan dapat menjadi sumber informasi ilmiah terkait pengelolaan ekosistem pesisir, termasuk ekosistem lamun.

\section{Metode Penelitian}

\subsection{Waktu dan Lokasi Penelitian}

Penelitian mengenai struktur komunitas perifiton dilakukan selama kurun waktu 4 bulan yang dimulai dari bulan Februari 2016 - Mei 2016. Penelitian dilakukan pada saat surut dengan tujuan untuk mempermudah penghitungan kerapatan lamun dan pengambilan sampe perifiton.

Penelitian mengenai struktur komunitas perifiton dilakukan di kawasan pantai Sanur yang meliputi Pantai Sanur, Pantai Shindu, Pantai Semawang, dan Pantai Mertasari (Gambar 1), sedangkan untuk identifikasi perifiton dilakukan di Laboratorium Kelautan Fakultas Kelautan dan

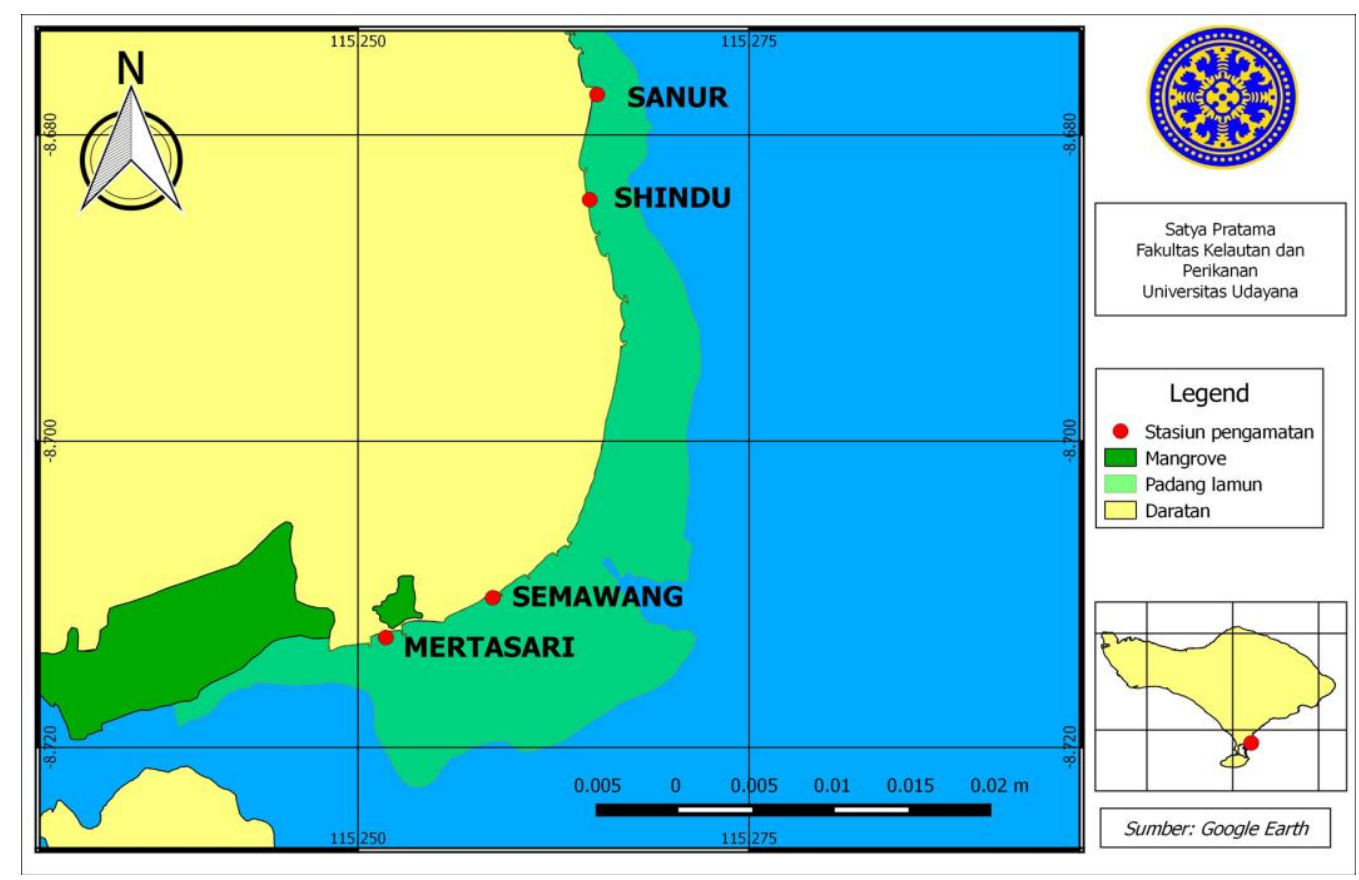

Gambar 1. Lokasi penelitian 
Perikanan Universitas Udayana.

\subsection{Alat dan Bahan}

Alat dan bahan yang digunakan pada penelitian ini adalah seperti GPS (Global Positioning System), $\mathrm{pH}$ pen, refraktometer, dan DO meter yang digunakan untuk pengambilan data parameter fisika-kimia. Cutter atau silet digunakan untuk mengerik sampel perifiton pada lamun. ADS (Alat Dasar Selam) untuk mempermudah penghitungan lamun. Lugol dan formalin untuk ditambahkan pada sampel perifiton sebagai pengawet dan pewarna sampel.

\subsection{Pengambilan Data dan Parameter Perairan}

\subsubsection{Lamun}

Penentuan stasiun yang diambil pada setiap tempat pengambilan data menggunakan metode purposive sampling, yaitu pengambilan yang dilakukan berdasarkan pertimbangan serta tujuan tertentu. Terdapat 4 stasiun pengambilan data, dimana setiap stasiun terdiri dari 2 substasiun Thalassia hemprichii (TH) dan 2 substasiun Cymodocea rotundatta (CR). Substasiun ditentukan berdasarkan metode random sampling, yaitu dengan mencari titik substasiun yang memiliki kerapatan Thalassia hemprichii (TH) dan Cymodocea rotundatta $(\mathrm{CR})$ yang tinggi.

\subsubsection{Perifiton}

Pada setiap stasiun yang sudah ditentukan sebelumnya, diambil lamun jenis Thalasia hemprichii dan Cymodocea rotundatta secara acak sebanyak 5 tegakan. Dari setiap tegakan lamun tersebut dilakukan pengamatan perifiton dengan cara mengerik permukaan daun lamun (Sarbini et al., 2015). Sampel perifiton kemudian ditaruh pada botol sampel yang sudah terisi air laut sebanyak 20 $\mathrm{ml}$, kemudian ditetesi larutan formalin $4 \%$ sebanyak 1 tetes dan ditambahkan lugol sebagai pewarna. Botol sampel kemudian diberi label sebagai penanda stasiun pengambilan sampel.

Sampel perifiton yang sudah dimasukkan ke dalam botol sampel kemudian diamati di bawah mikroskop sebanyak 3 kali ulangan menggunakan Sedgwick-Rafter Counting Cell. Metode pengamatan yang digunakan adalah metode 5 titik, dimana kelimpahan perifiton hanya dilihat pada pojok kanan dan kiri bagian atas, pojok kanan dan kiri bagian bawah, serta bagian tengah. Jenis-jenis perifiton yang didapat kemudian diidentifikasi berdasarkan Coastal Plankton Photo Guide for European Seas.

\subsubsection{Parameter fisika-kimia perairan}

Parameter perairan yang diambil adalah suhu, salinitas, $\mathrm{pH}, \mathrm{DO}$ (dissolved oxygen), nitrat, fosfat serta TSS. Data suhu, salinitas, $\mathrm{pH}$ dan DO (dissolved oxygen) diambil satu kali secara in situ di setiap stasiun pengamatan, untuk data nitrat dan fosfat dilakukan analisis data di Laboratorium Dinas Kesehatan Provinsi Bali, sedangkan analisis TSS dilakukan di Laboratorium Kelautan Universitas Udayana.

\subsection{Analisa Data}

\subsubsection{Persen penutupan lamun}

Penutupan adalah luasan area yang tertutupi oleh lamun yang di lihat menggunakan metode visual dengan rumus (English et al., 1994) sebagai berikut:

$$
C=\frac{\sum\left(M_{i} x F_{i}\right)}{\sum F}
$$

Keterangan:

C : Nilai persen penutupan lamun

$M_{i} \quad$ : Nilai tengah kelas penutupan ke-i

$F_{i} \quad$ : Frekuensi munculnya kelas penutupan ke-i

$\sum F \quad$ : Jumlah total frekuensi seluruh penutupan kelas

Kelas penutupan yang digunakan untuk mencatat kelimpahan lamun disajikan pada Tabel 1.

Tabel 1.

Penutupan lamun

\begin{tabular}{cccc}
\hline Kelas & $\begin{array}{c}\text { Nilai } \\
\text { penutupan }\end{array}$ & $\begin{array}{c}\text { Persen } \\
\text { penutupan }\end{array}$ & $\begin{array}{c}\text { Nilai tengah } \\
(\mathrm{Mi})\end{array}$ \\
\hline 5 & $1 / 2-$ Seluruhnya & $50-100$ & 75 \\
4 & $1 / 4-1 / 2$ & $25-50$ & 37.5 \\
3 & $1 / 8-1 / 4$ & $12.5-25$ & 18.75 \\
2 & $1 / 16-1 / 8$ & $6.25-12.5$ & 9.38 \\
1 & $<1 / 16$ & $<6.25$ & 3.13 \\
0 & Kosong & 0 & 0 \\
\hline
\end{tabular}

\subsubsection{Kerapatan lamun}

Kerapatan jenis (Di) adalah jumlah individu (tegakan) persatuan luas. Kerapatan masing- 
masing jenis pada setiap stasiun dihitung dengan menggunakan rumus (Brower et al., 1998).

$$
D_{i}=\frac{n_{i}}{A}
$$

Keterangan:

$D_{i}$ : Jumlah individu ke-i per satuan luas (ind $/ \mathrm{m}^{2}$ )

$n_{i}:$ Jumlah individu ke-i (ind)

$A$ : Luas transek kuadrat $\left(\mathrm{m}^{2}\right)$

\subsubsection{Kelimpahan perifiton}

Kelimpahan jenis perifiton pada setiap stasiun pengamatan dihitung menggunakan rumus modifikasi Eaton et al., (1995) sebagai berikut:

$$
N=\frac{n \times A_{c g} \times V_{t}}{A_{a} \times V_{s} \times A_{s}}
$$

Keterangan:

$N$ : Kelimpahan perifiton (ind $/ \mathrm{mm}^{2}$ )

$n \quad$ : Jumlah perifiton yang diamati (ind)

$A_{c g} \quad$ : Luas lamun yang dikerik $\left(\mathrm{mm}^{2}\right)$

$V_{t} \quad$ : Volume konsentrasi pada botol sampel (ml)

$A_{a} \quad$ : Luas daerah pengamatan $\left(\mathrm{mm}^{2}\right)$

$V_{s} \quad$ : Volume konsentrasi pada cover glass (ml)

$A_{s} \quad$ : Luas penampang pada cover glass $\left(\mathrm{mm}^{2}\right)$

\subsubsection{Keanekaragaman $\left(\mathrm{H}^{\prime}\right)$}

Nilai keanekaragaman dihitung berdasarkan modifikasi indeks Shannon - Wiener (Odum, 1971) sebagai berikut:

$$
H^{\prime}=-\sum_{i=1}^{n} p i \operatorname{Ln} p i
$$

Keterangan:

$H^{\prime} \quad$ : Indeks keanekaragaman

$p_{i} \quad$ : Proporsi jenis ke-I $\left(n_{i} / N\right)$

$n_{i} \quad$ : Jumlah individu jenis ke-i (sel)

$N \quad$ : Jumlah total individu (sel)
Kriteria indeks keanekaragaman tersebut diklasifikasikan sebagai berikut:

$H^{\prime}<1 \quad$ : Keanekaragaman rendah

$1 \leq H^{\prime} \leq 3 \quad$ : Keanekaragaman sedang

$H^{\prime}>3 \quad$ : Keanekaragaman tinggi

\subsubsection{Keseragaman (E)}

Mengetahui nilai keseragaman penyebaran spesies dalam komunitas alga epifit digunakan indeks keseragaman yaitu rasio keanekaragaman dan nilai maksimumnya (Odum, 1971):

$$
E=\frac{H^{\prime}}{H^{\prime} m a k s}
$$

Keterangan:

E : Indeks keseragaman Evenness

$H^{\prime} \quad$ : Indeks keanekaragaman Shannon

$H^{\prime}$ maks : Ln S, dimana $S$ adalah jumlah taksa

Dengan kriteria nilai $E$ (indeks keseragaman Evenness) sebagai berikut:

$$
\begin{array}{ll}
E<0.4 & : \text { Keseragaman rendah } \\
0.4 \leq E \leq 0.6 & : \text { Keseragaman sedang } \\
E>0.6 & : \text { Keseragaman tinggi }
\end{array}
$$

\subsubsection{Dominansi $(\mathrm{C})$}

Spesies yang paling dominan dapat menentukan atau mengendalikan kehadiran jenis lainnya berdasarkan indeks dominansi Simpson (Odum, 1971):

$$
C=\sum_{i=1}^{n}\left(\frac{n_{i}}{N}\right)^{2}
$$

Keterangan :

C : Indeks dominansi Simpson

$n_{i} \quad$ : Jumlah individu jenis ke-I (sel)

$N$ : Jumlah total individu (sel)

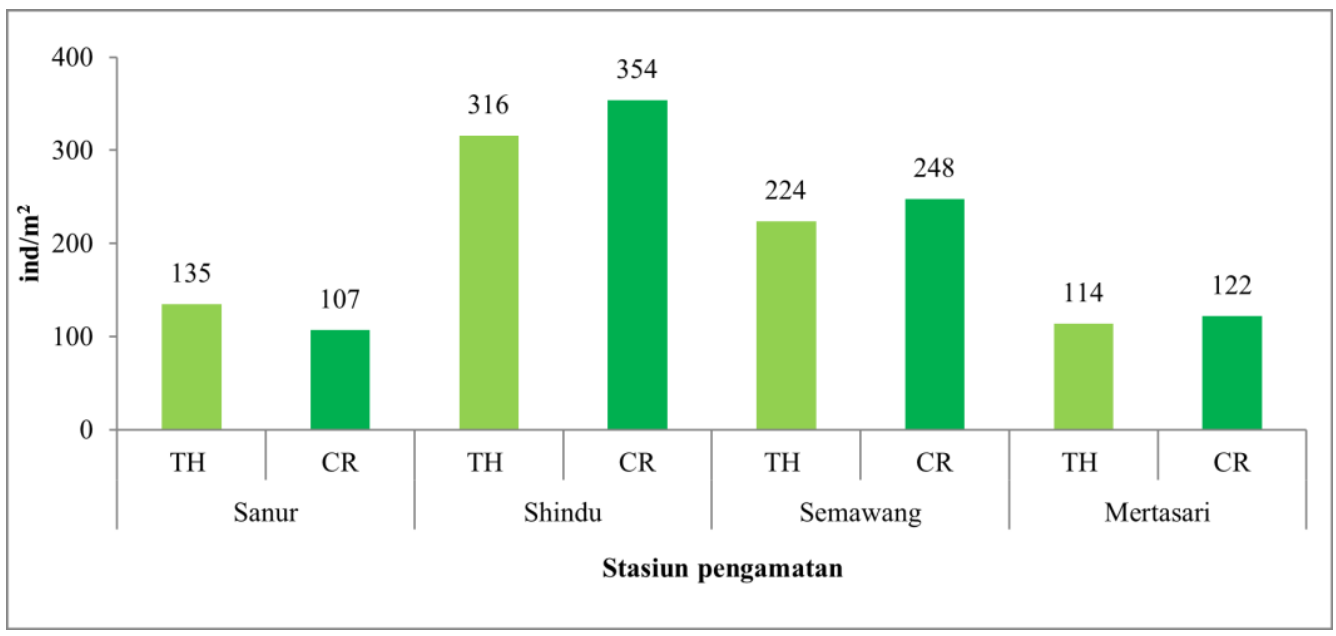

Gambar 2. Kerapatan lamun 
Nilai indeks dominansi berkisar antara 0-1 apabila:

$$
\begin{array}{ll}
0<C<0.3 & \text { : Dominansi rendah } \\
0.3 \leq C \leq 0.6 & \text { : Dominansi sedang } \\
0.6<C \leq 1 & \text { : Dominansi tinggi }
\end{array}
$$

\subsubsection{Principal Component Analysis (PCA)}

Adapun parameter yang digunakan dalam analisis PCA adalah suhu, salinitas, $\mathrm{pH}$, dissolved oxygen (DO), nitrat, fosfat, TSS, dan kelimpahan perifiton. Software yang digunakan dalam pengolahan data PCA adalah Statistica 13. Variabel yang digunakan sebagai input dalam analisis PCA adalah suhu, salinitas, $\mathrm{pH}$, dissolved oxygen (DO), nitrat, fosfat, TSS, dan kelimpahan perifiton sebagai variabel kuantitatif (kolom) serta substasiun pengamatan sebagai individu statistik (baris). Output yang dihasilkan adalah dalam bentuk grafik kombinasi linear hasil interpretasi active variable terhadap supplementary variable, dimana setiap axis (faktor) dapat diinterpretasikan sebagai korelasi dengan variabel-variabel asal.

\section{Hasil dan Pembahasan}

Berdasarkan nilai parameter perairan (suhu, salinitas, $\mathrm{pH}, \mathrm{DO}$, nitrat, serta fosfat) yang di ukur pada masing - masing lokasi penelitian (Sanur, Shindu, Semawang, dan Mertasari) didapatkan hasil seperti yang tersaji pada Tabel 2.

\subsection{Parameter Fisika-Kimia Perairan}

3.1.1 Suhu

Suhu perairan yang didapatkan sepanjang Kandungan oksigen terlarut di perairan kawasan pantai Sanur berkisar antara 29,1 - 31,6 ${ }^{\circ} \mathrm{C}$. Kisaran suhu tersebut masih dalam toleransi optimal bagi lamun serta perifiton untuk hidup. Adapun suhu optimal untuk pertumbuhan lamun perubahan suhu antara $28-34{ }^{\circ} \mathrm{C}$. Sedangkan suhu optimal untuk perifiton hidup adalah $27{ }^{\circ} \mathrm{C}$ $31{ }^{\circ} \mathrm{C}$ (Siagian, 2012 ; Novianti et al., 2013).

\subsubsection{Salinitas}

Nilai salinitas yang didapatkan di setiap stasiun tidak terlalu berbeda siginifikan, sehingga relatif sama. Adapun nilai salinitas yang didapatkan berkisar antara 31 - 32 ppt. Kisaran salinitas optimum yang dapat ditolerir lamun dan perifiton 2013), sehingga nilai salinitas tersebut masih dapat di toleransi oleh lamun dan perifiton. Pada umumnya salinitas di perairan pesisir selalu berfluktuasi karena dipengaruhi oleh berbagai faktor, antara lain pola sirkulasi air, penguapan, curah hujan, serta aliran sungai

\subsection{3 $\mathrm{pH}$}

Nilai pH di sepanjang kawasan pantai Sanur relatif asam mendekati normal, yang berkisar antara 6,6 6,8. Nilai tersebut merupakan kisaran yang optimal bagi biota laut untuk tumbuh dan berkembang, tak terkecuali lamun dan perifiton. Adapun kisaran $\mathrm{pH}$ optimal untuk biota laut hidup adalah $6,5-8,5$.

\subsubsection{DO} berkisar 28 - $30{ }^{\circ} \mathrm{C}$, namun dapat mentolerir adalah sampai dengan 35 ppt (Novianti et al.,

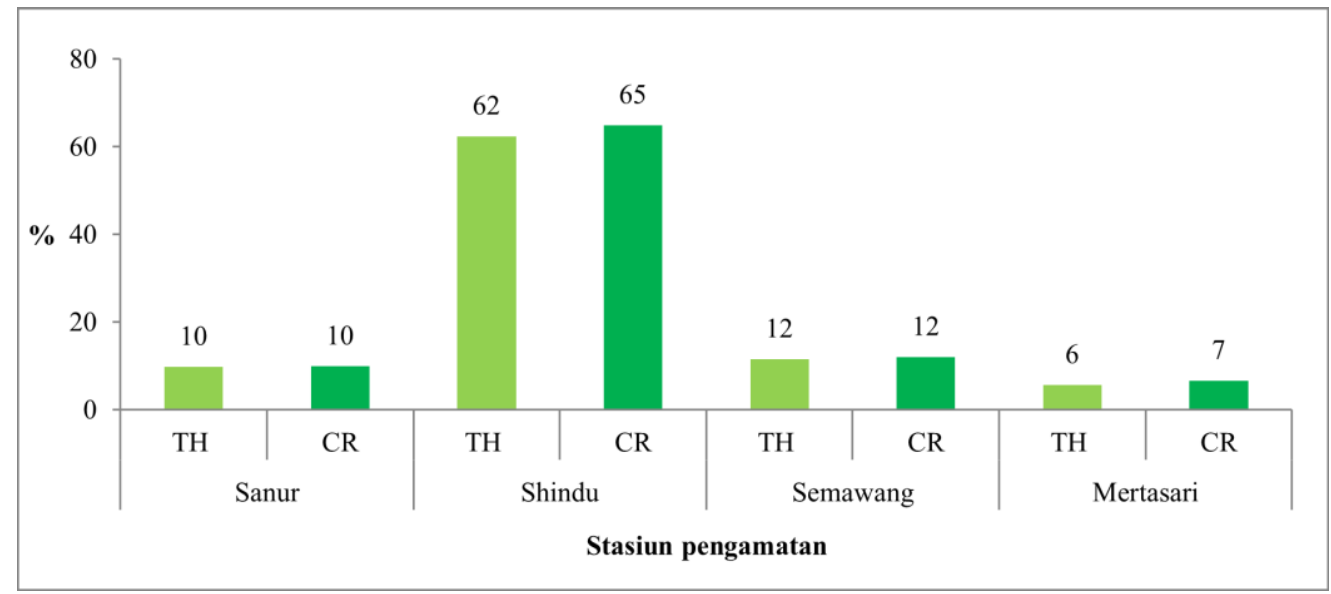

Gambar 3. Persen penutupan lamun 


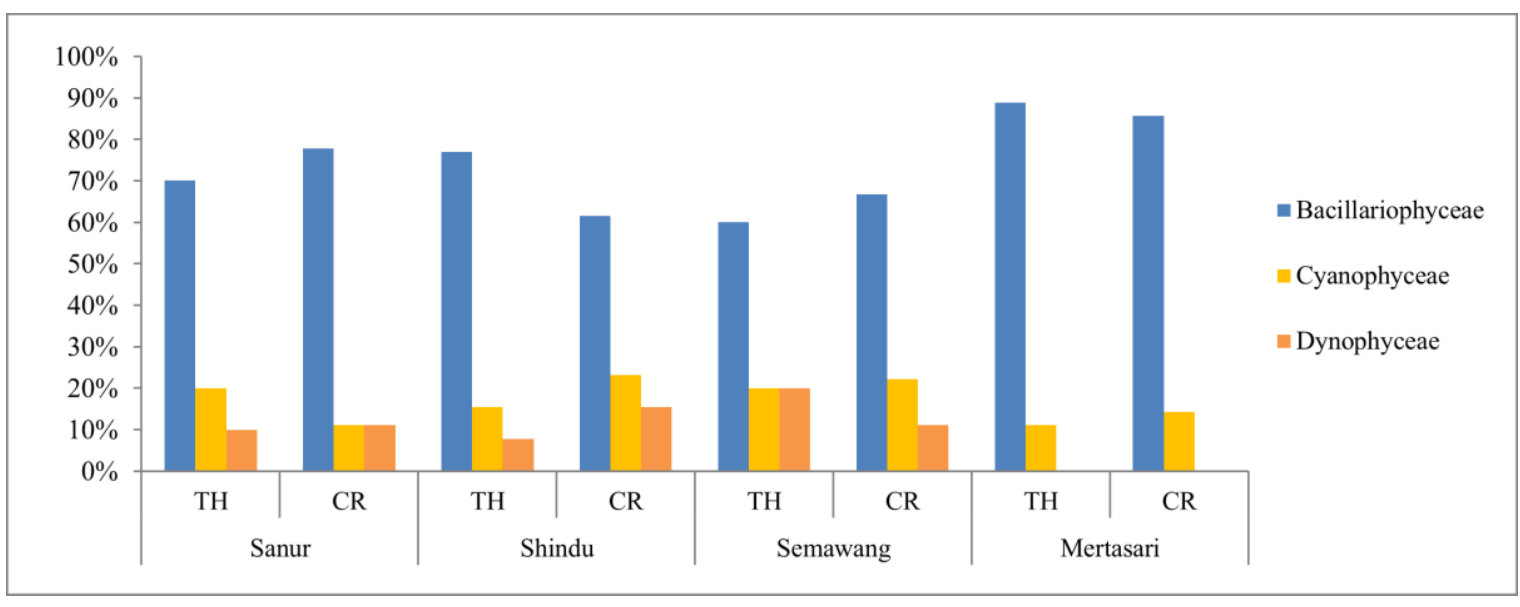

Gambar 4. Komposisi jenis perifiton

memegang peranan penting terhadap kelangsungan hidup biota laut. Perairan dengan kandungan DO yang stabil akan memiliki jumlah spesies yang melimpah. Kisaran nilai DO yang didapatkan relatif sama yakni berkisar antara 5,3 $5,4 \mathrm{mg} / \mathrm{L}$.

\subsubsection{Nitrat}

Nitrat merupakan salah satu nutrien penting yang dibutuhkan oleh organisme laut. Kisaran nitrat yang didapat di kawasan pantai Sanur berkisar antara 0,04 - 1,3 mg/L. Kandungan tertinggi ditemukan di pantai Shindu dengan nilai sebesar 1,3 mg/L. Hal ini menyebabkan tingginya kerapatan (Gambar 2) dan penutupan lamun (Gambar 3) di daerah tersebut. Taniwaki et al., (2013) menyebutkan bahwa kandungan nitrat di perairan dapat mempengaruhi biomassa perifiton di suatu perairan.

\subsubsection{Fosfat}

Kisaran fosfat yang ditemukan berada pada kisaran 0,01 - 0,45 mg/L. Kandungan fosfat tertinggi ditemukan pada pantai Sanur sebesar 0,45 mg/L. Hal ini diduga karena banyaknya serasah daun lamun, baik yang mati secara alami ataupun terpotong akibat tingginya aktivitas manusia di pantai tersebut seperti pariwisata (speed boat, memancing, berenang, snorkeling) ataupun terpotong propeler kapal boat. Hal ini sejalan dengan yang dinyatakan oleh Ulqodry et al., (2010) bahwa tingginya kandungan fosfat berasal dari jasad flora atau fauna biota laut yang mati. Sedangkan kandungan fosfat terendah ditemukan pada pantai Mertasari, dengan nilai sebesar 0,01 $\mathrm{mg} / \mathrm{L}$. hal ini karena daerah tersebut berbatasan langsung dengan ekosistem mangrove, yang diduga menjadi filter bagi buangan limbah organik yang menuju ke arah pantai.

\subsubsection{TSS}

Keberadaan suspensi terlarut dalam perairan, baik yang bersifat organik maupun anorganik akan mengakibatkan perairan tersebut menjadi keruh sehingga menghambat sinar matahari yang masuk

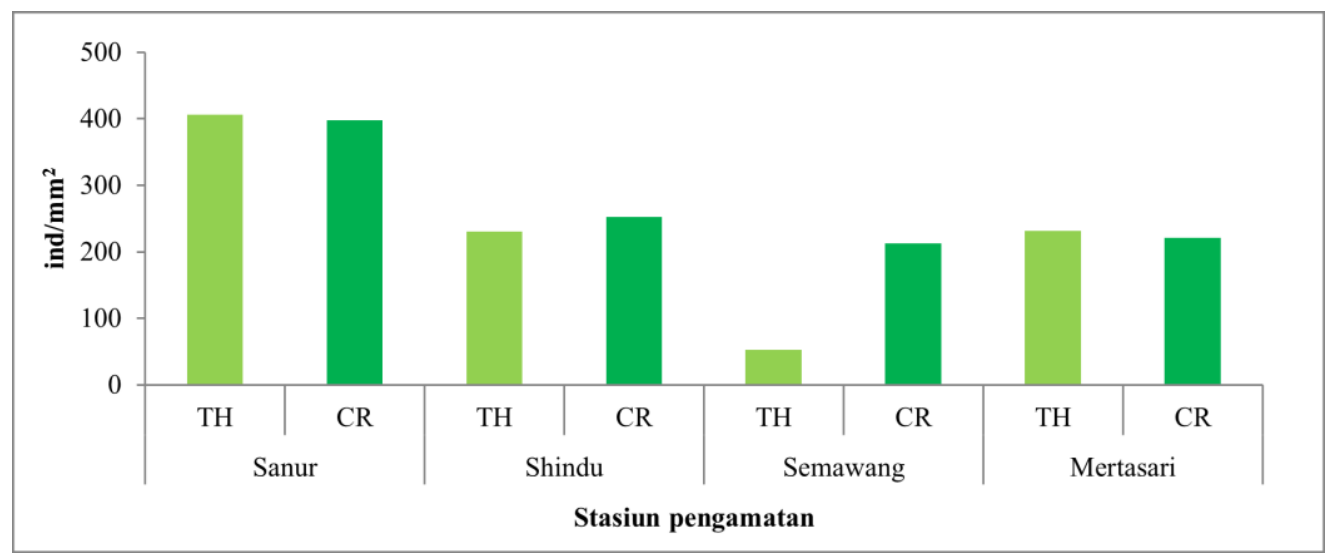

Gambar 5. Persen penutupan lamun 


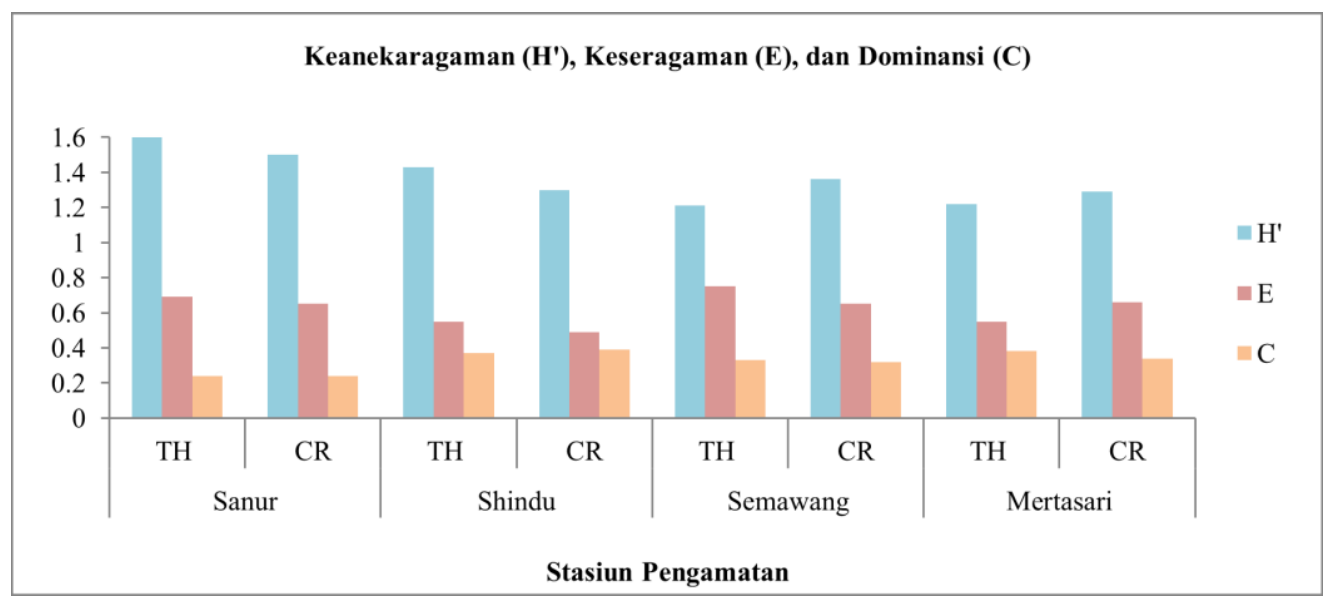

Gambar 6. Indeks $\mathrm{H}^{\prime}$, E, dan $\mathrm{C}$ perifiton

ke perairan dan menyebabkan proses fotosintesis, baik oleh lamun ataupun perifiton menjadi terganggu.

Kisaran nilai TSS yang didapatkan berkisar antara 296 - 539 mg/L. Pantai Sanur memiliki kandungan padatan terlarut tertinggi, hal ini diduga disebabkan oleh padatnya aktivitas wisatawan di daerah tersebut seperti memancing, berenang, penambatan jangkar kapal, lalu lalang kapal nelayan yang dapat mengakibatkan terjadinya pengadukan substrat dasar ke kolom perairan.

Berdasarkan Gambar 2, dapat dilihat bahwa kisaran lamun Thalassia hemprichii yang didapat berkisar antara 114 - 316 ind $/ \mathrm{m}^{2}$, sedangkan lamun Cymodocea rotundatta berkisar antara 107 - 354 ind $/ \mathrm{m}^{2}$. Kerapatan tertinggi baik lamun Thalassia hemprichii maupun Cymodocea rotundatta ditemukan di pantai Shindu, hal ini diduga karena tingginya kandungan nitrat yang ditemukan di daerah tersebut, yang secara langsung dapat mempengaruhi kesuburan tumbuhan lamun.
Sedangkan kerapatan terendah ditemukan di pantai Sanur dan Semawang. Kandungan TSS yang cukup tinggi di daerah tersebut diduga menjadi penyebab rendahnya nilai kerapatan lamun. Kandungan TSS yang tinggi di perairan akan mengakibatkan perairan tersebut menjadi keruh sehingga menghambat sinar matahari yang masuk ke perairan dan menyebabkan proses fotosintesis, baik oleh lamun ataupun perifiton menjadi terganggu.

Gambar 3 menggambarkan persen penutupan lamun yang didapatkan di kawasan pantai Sanur. Terlihat pada Gambar 3 bahwa pantai Shindu memiliki persen penutupan yang paling tinggi di antara pantai yang lain, dengan nilai $62 \%$ pada lamun Thalassia hemprichii dan $65 \%$ pada lamun Cymodocea rotundatta. Hal ini mengindikasikan kedua jenis lamun tersebut tumbuh dengan subur di pantai tersebut. Secara visual, lamun jenis lain juga cukup banyak ditemukan di pantai Shindu. Penutupan lamun yang tinggi, akan memperbesar kemungkinan perifiton untuk menempel pada
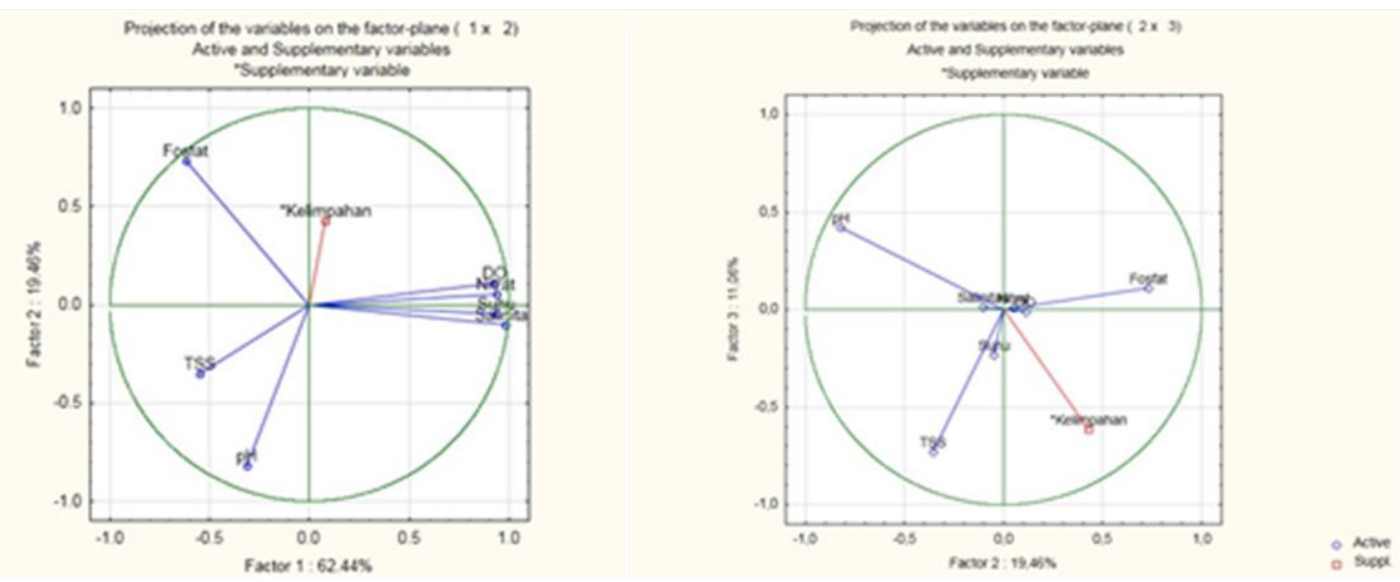

Gambar 7. Persen penutupan lamun 


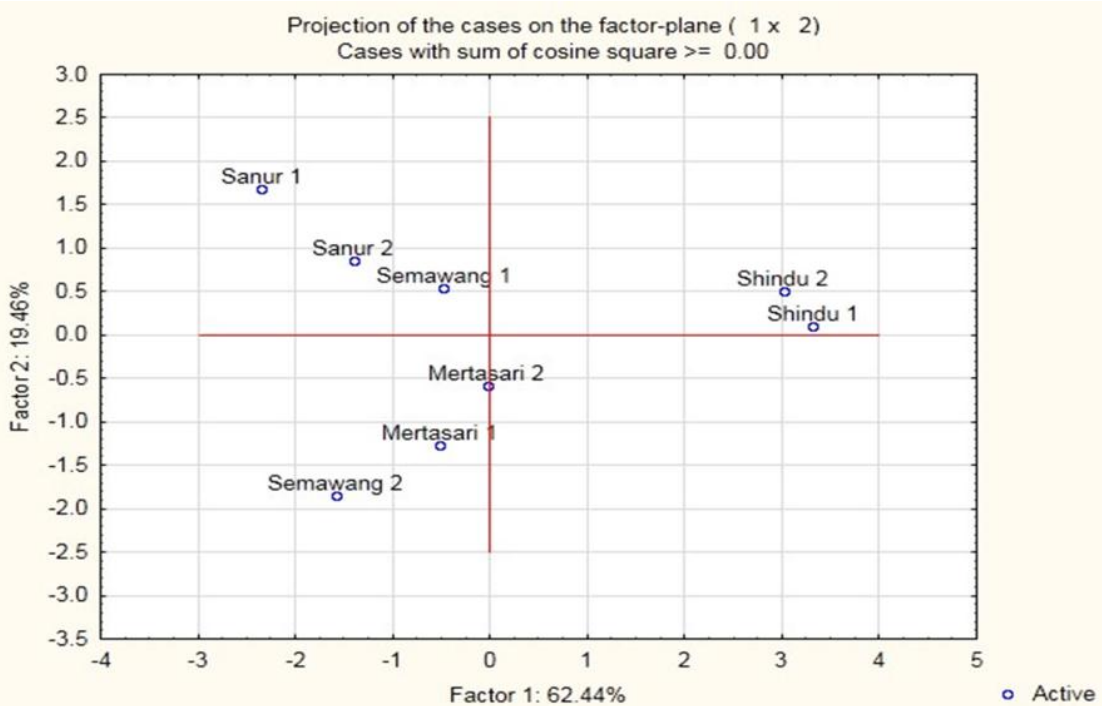

Gambar 8. Analisis penyebaran stasiun pada lamun Thalassia hemprichii

permukaan daun lamun. Dengan morfologi Thalassia hemprichii dan Cymodocea rotundatta yang memiliki daun pendek, serta jaraknya yang dekat dengan dasar perairan, memperbesar peluang penempelan perifiton akibat pergerakan air yang membawa organisme yang bersifat planktonik untuk menempel.

Tabel 2.

Data parameter fisika-kimia perairan

\begin{tabular}{|c|c|c|c|c|}
\hline Parameter & Sanur & Shindu & Semawang & Mertasari \\
\hline Suhu $\left({ }^{\circ} \mathrm{C}\right)$ & 29.4 & 31.6 & 29.1 & 30.4 \\
\hline Salinitas (ppt) & 31 & 31.2 & 31.5 & 32 \\
\hline $\mathrm{pH}$ & 6.6 & 6.6 & 6.7 & 6.8 \\
\hline $\mathrm{DO}(\mathrm{mg} / \mathrm{L})$ & 5.4 & 5.3 & 5.3 & 5.4 \\
\hline $\mathrm{N}(\mathrm{mg} / \mathrm{L})$ & 0.04 & 1.3 & 0.29 & 0.17 \\
\hline $\mathrm{P}(\mathrm{mg} / \mathrm{L})$ & 0.45 & 0.08 & 0.2 & 0.01 \\
\hline TSS (mg/L) & 539 & 296 & 323 & 417 \\
\hline
\end{tabular}

\subsection{Komposisi jenis perifiton}

Jumlah jenis perifiton yang ditemukan di setiap stasiun diketahui bahwa persentase komposisi masing-masing kelas juga berbeda satu sama lainnya, baik antar stasiun pengamatan maupun antar jenis lamun.

Berdasarkan hasil pengamatan komposisi perifiton di kawasan pantai Sanur, ditemukan 22 jenis yang terdiri dari 3 kelas, yaitu Bacillariophyceace (17 jenis), Dynophyceae (2 jenis), dan Cyanophyceae (3 jenis). Jenis yang paling sering ditemukan adalah Nitzchia $s p$, Amphora sp, dan Rhizosolenia sp.

Pada Gambar 4 terlihat bahwa kelas Bacillariophyceae memiliki persentase yang sangat tinggi di antara kelas perifiton lainnya. Hal ini menunjukkan jenis perifiton yang termasuk ke dalam kelas Bacillariophyceae jumlahnya sangat banyak, melimpah, dan mendominasi di antara jenis lainnya. Keberadaan kelompok Bacillariophyceae di perairan memang sering mendominasi dan memiliki kelimpahan yang tinggi kecuali pada sungai yang berlumpur (Junda et al., 2013 ; Novianti et al., 2013).

Pada Gambar 5, terlihat bahwa kelimpahan perifiton pada daun Thalassia hemprichii berkisar antara 52,67 - 406,5 ind $/ \mathrm{mm}^{2}$, sedangkan kelimpahan perifiton pada daun Cymodocea rotundatta berkisar antara 212,5 - 397,3 ind $/ \mathrm{mm}^{2}$. Kelimpahan perifiton tertinggi, baik pada lamun Thalassia hemprichii maupun Cymodocea rotundatta ditemukan pada pantai Sanur. Tingginya kelimpahan perifiton pada daerah ini diduga diakibatkan oleh tingginya kandungan fosfat di pantai Sanur yang ikut mendukung perkembangan perifiton (Tabel 2). Selain itu, berdasarkan hasil analisis PCA yang telah dilakukan pada daun Thalassia hemprichii (Gambar 7) dan Cymodocea rotundatta (Gambar 8), didapatkan bahwa kandungan TSS yang tinggi pada pantai Sanur (Tabel 2) memiliki pengaruh paling kuat terhadap kelimpahan perifiton. Adapun kandungan TSS tersebut memiliki hubungan yang berbanding lurus terhadap 


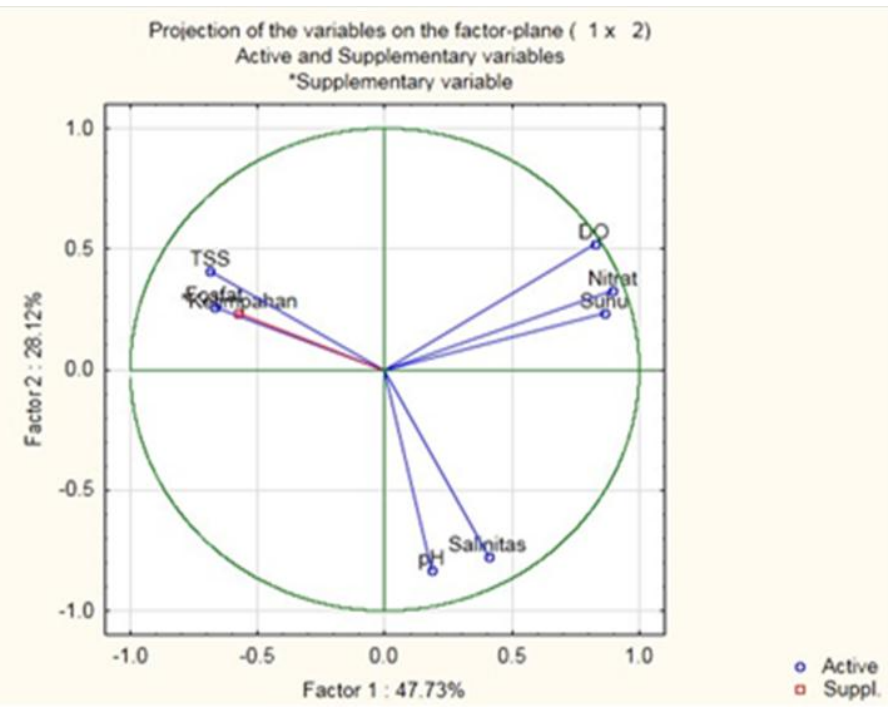

Gambar 9. Analisis PCA pada lamun Cymodocea rotundatta

kelimpahan perifiton, sehingga apabila kandungan TSS tinggi, maka kelimpahan perifiton juga akan tinggi. Begitupun sebaliknya apabila kandungan TSS rendah, maka kelimpahan perifiton akan rendah juga.

\subsection{Indeks $H^{\prime}, E$, dan C Perifiton}

Berdasarkan Gambar 6 tersebut di atas, terlihat bahwa indeks keanekaragaman perifiton pada lamun Thalassia hemprichii berkisar 1,2 - 1,6, sedangkan pada lamun Cymodocea rotundatta berkisar 1,2 - 1,5. Berdasarkan Odum (1971), maka keanekaragamannya tergolong sedang. Keseragaman perifiton pada lamun Thalassia hemprichii berkisar antara 0,5-0,7 dan Cymodocea rotundatta berkisar antara 0,4-0,6. Berdasarkan indeks Eveness maka keseragaman tersebut tergolong sedang sampai tinggi. Nilai dominansi perifiton pada lamun Thalassia hemprichii dan Cymodocea rotundatta berkisar antara 0,2 - 0,3. Berdasarkan indeks dominansi Simpson, maka dominansinya tergolong rendah sampai sedang.

Keadaan struktur komunitas tersebut mencerminkan bahwa kondisi perairan di kawasan pantai Sanur, Shindu, Semawang, serta Mertasari masih dalam keadaan stabil namun cenderung berubah akibat adanya aktivitas antropogenik pada masing-masing daerah tersebut.

\subsection{PCA Thalassia hemprichii}

Hasil PCA Gambar 7 memperlihatkan bahwa total informasi yang diberikan dari dua sumbu utama (faktor 1 dan faktor 2) sebesar 81,90\% dari ragam total, sedangkan faktor 2 dan 3 menjelaskan total informasi sebesar 30,51 \% dari ragam total. Sebagian besar informasi terpusat pada faktor 1 , dimana sumbu ini menjelaskan $62,44 \%$ dari ragam total dengan nilai akar ciri (eigen value) sebesar 4,37, faktor 2 menjelaskan 19,46\% dari ragam total dengan nilai akar ciri (eigen value) sebesar 1,36, sedangkan faktor 3 menjelaskan 11,05 \% dari ragam total dengan nilai akar ciri (eigen value) sebesar 0,77. Parameter DO, nitrat, suhu, dan salinitas, dapat dijelaskan pada faktor 1 , faktor 2 dijelaskan oleh parameter $\mathrm{pH}$ dan TSS, sedangkan faktor 3 dijelaskan oleh parameter TSS. Kelimpahan perifiton dapat diinformasikan oleh faktor 3 dibandingkan dengan faktor 2, sehingga parameter yang berpengaruh terhadap kelimpahan adalah TSS.

Gambar 8 menunjukkan stasiun pengamatan di Pantai Shindu (1 dan 2) dan Sanur (2) lebih dapat dijelaskan oleh faktor 1 , sehingga tercirikan oleh parameter DO, nitrat, suhu, serta salinitas, sedangkan stasiun pengamatan di Pantai Sanur (1), Semawang (1 dan 2), Mertasari (1 dan 2) dapat dijelaskan oleh faktor 2 yang dicirikan oleh parameter $\mathrm{pH}$ dan TSS.

\subsection{PCA Cymodocea rotundatta}

Gambar 9 memperlihatkan bahwa total informasi yang diperoleh dari faktor 1 dan faktor 2 sebesar $75,84 \%$ dari ragam total. Faktor 1 dengan nilai akar ciri (eigen value) 3,34 menjelaskan informasi sebesar $47,73 \%$ dari ragam total, sedangkan faktor 


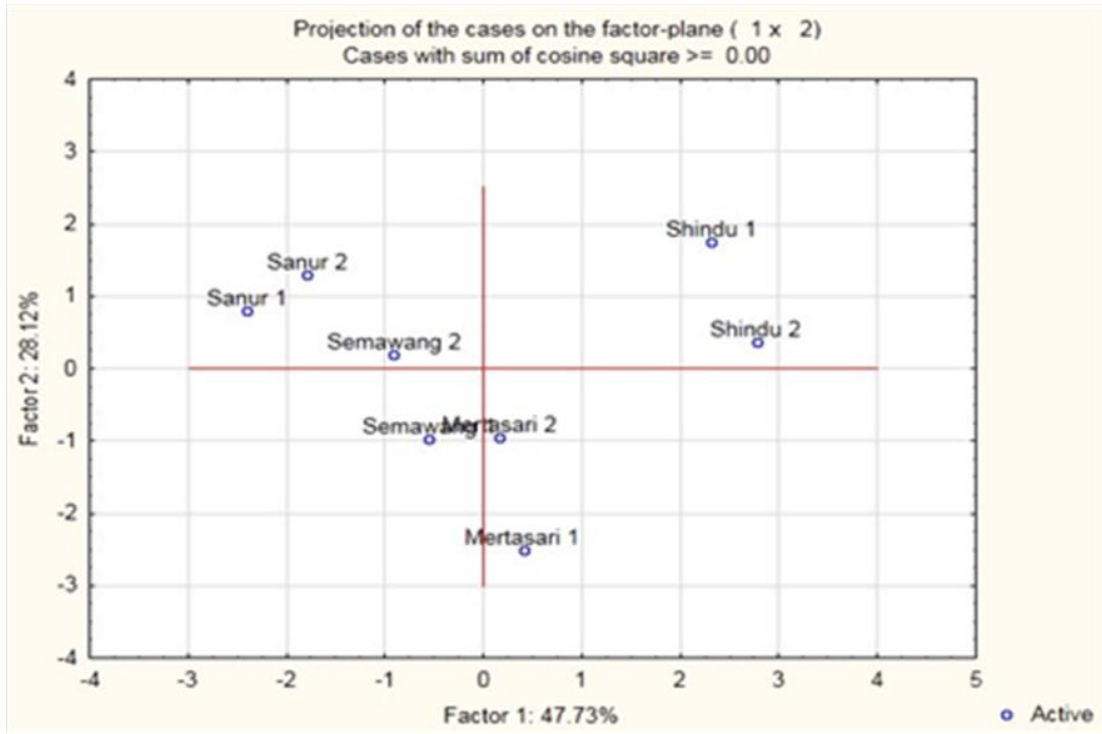

Gambar 10. Analisis penyebaran stasiun pada lamun Cymodocea rotundatta

2 yang memiliki nilai akar ciri (eigen value) 1,96 dapat menjelaskan informasi sebesar 28,12\% dari ragam total. Faktor 1 dapat dijelaskan oleh parameter DO, nitrat, suhu, TSS, dan fosfat, sedangkan faktor 2 dapat dijelaskan oleh parameter salinitas dan $\mathrm{pH}$.

Kelimpahan perifiton lebih dapat diinformasikan oleh faktor 1, sehingga parameter yang mempengaruhi kelimpahan perifiton adalah DO, nitrat, suhu, fosfat ,serta TSS. Kelima parameter tersebut memiliki hubungan yang berbanding lurus terhadap kelimpahan perifiton.

Gambar 10 menunjukkan bahwa stasiun pengamatan Pantai Sanur (1 dan 2), Shindu (1 dan 2), dan Semawang (2) dapat diinformasikan oleh faktor 1, sehingga parameter yang mencirikan pantai tersebut adalah DO, nitrat, suhu, fosfat, dan TSS. Sedangkan pantai Semawang (1) dan Mertasari (1 dan 2) memiliki kontribus lebih dapat dijelaskan oleh faktor 2, sehingga dicirikan oleh parameter $\mathrm{pH}$ dan salinitas.

\section{Simpulan}

Berdasarkan hasil penelitian yang telah dilakukan, ditemukan 22 jenis perifiton yang terdiri dari 3 kelas, yaitu Bacillariophyceace (17 jenis), Dynophyceae (2 jenis), dan Cyanophyceae (3 jenis). Kelas Bacillariophyceae merupakan yang paling mendominasi dan melimpah di semua stasiun pengamatan, dengan jenis yang paling sering ditemukan adalah Amphora sp, Nitzchia sp, dan Rhizosolenia sp.
Nilai keanekaragaman perifiton baik pada lamun Thalassia hemprichii dan Cymodocea rotundatta di semua stasiun tergolong sedang, keseragaman perifiton tergolong sedang sampai tinggi, serta nilai dominansi tergolong rendah sampai sedang. Keadaan struktur komunitas tersebut mencerminkan bahwa kondisi perairan di kawasan pantai Sanur, Shindu, Semawang, serta Mertasari masih dalam keadaan stabil namun cenderung berubah akibat adanya aktivitas antropogenik pada masing-masing daerah tersebut.

Analisis PCA menunjukkan kelimpahan perifiton pada lamun Thalassia hemprichii dipengaruhi oleh kandungan TSS, yang memiliki hubungan berbanding lurus. Kelimpahan perifiton pada lamun Cymodocea rotundatta dipengaruhi oleh DO, nitrat, suhu, TSS dan fosfat. DO, nitrat, dan suhu memiliki hubungan yang berbanding terbalik terhadap kelimpahan perifiton, sedangkan TSS dan fosfat memiliki hubungan yang berbanding lurus terhadap kelimpahan peifiton.

\section{Ucapan terimakasih}

Penulis mengucapkan terima kasih kepada Program Bidik Misi atas bantuan biaya pendidikan selama perkuliahan dan seluruh pihak yang telah memberikan masukan dan bimbingan dalam pembuatan jurnal ilmiah ini. Terimakasih juga penulis ucapkan kepada keluarga besar Fakultas Kelautan dan Perikanan UNUD, teman-teman satu 
angkatan yang tidak bisa penulis ucapkan satu persatu atas segala bantuan yang telah diberikan.

\section{Daftar Pustaka}

Brower , J. E, Zar J.H, Von Ende. (1998). Field and Laboratory Methods For General Ecology. Third Edition. USA: Wm. C. Brown Publisher.

Dewi, R. K. (2012). Pengelolaan Ekosistem Lamun Kawasan Wisata Pantai Sanur Kota Denpasar Provinsi Bali. Tesis. Bogor: Sekolah Pasca Sarjana IPB

Eaton, Andrew D, Clesceri, Lenore S, Rice, Eugene W, Greenburg, Arnold E, Franson, Mary Ann H. (1995). Standard methods for the examination of water and wastewater (19 ${ }^{\text {th }}$ Edition), Baltimore, Maryland: American Public Health Association.

English, S., C. Wilkinson and V. Baker. (1994). Survey Manual for Tropical Marine Resources. Townsville: Australian Institute for Marine Science.

Fitriani., Maulana, F. (2015). Identifikasi Jenis Perifiton Sebagai Penentu Kualitas Air Di Sungai Ray 17 Kelurahan Berangas Barat Kabupaten Barito Kuala. Jurnal Pendidikan Hayati, 1(4), 44 - 49.

Indrawati, I., Sunardi, Ita F. (2010). Perifiton Sebagai Indikator Biologi Pada Pencemaran Limbah Domestik Di Sungai Cikuda Sumedang. In Prosiding Seminar Limnologi V: 76-86.

Junda, M., Hijriah., Hala, Y. (2013). Identifikasi Perifiton Sebagai Penentu Kualitas Air Pada Tambak Ikan Nila (Oreochromis niloticus), Bionature, 14(1), 16-24.

Kocak, F., Onen, A. (2014). Ephyphitic Bryozoan Community of Posidonia oceanica Delile Leaves in Two Different Meadows at Disturbed and Control Locations. Medit. Mar. Sci, 15(2), 390 - 397.

Mabrouk, L., Brahim, M. B., Hamza, A., Mahfoudhi, M., Bradai, M, N., (2014). A Comparison of Abundance and Diversity of Epiphytic Microalgal Assemblages on The Leaves of the Seagrasses Posidonia oceanica and Cymodocea nodosa Asch in Eastern Tunisia. Hindawi Journal of Marine Biology, 2014(1), 1- 10.

Novianti, M., Widyorini, N., Suprapto, J. (2013). Analisis Kelimpahan Perifiton Pada Kerapatan Lamun Yang Berbeda Di Perairan Pulau Panjang, Jepara. Journal of Management of Aquatic Resources, 2(3), 219 - 225

Odum, E. O. (1971). Fundamental of Ecology. $2^{\text {nd }}$ edition. Philadelpia: W. B. Saunders

Orbita, L. S. and Mukai, H. (2013). Relationship Between Epiphytes and The Photosyntetic Activity of Temperate Seagrasses. AAB Bioflux, 5(3), 163 - 168

Sarbini, R., Nugraha, Y., Kuslani, H. (2015). Teknik Sampling dan Pengamatan Kelimpahan Perifiton Di Ekosistem Lamun, Kepulauan Karimun Jawa, Jawa Tengah. BTL, 13(2), 91 - 96.

Siagian, M. (2012). Kajian Jenis dan Kelimpahan Perifiton Pada Eceng Gondok (Eichornia crassipes) Di Zona Litoral Waduk Limbungan Pesisir Rumbai, Riau. Akuatika, 3(2), 95 - 104

Tang, W., Cui, J., Shan, B., Wang, C., Zhang, W. (2014). Heavy Metal Accumulation By Periphyton Is Related To Eutrophication In The Hai River Basin, Northern China. PLOSone, 9(1), $1-6$.

Taniwaki, R. H., Magrin, A. G. E., Calijuri, M. C., Carlos, V. M. (2013). Biomass and Elemental Composition (C, $\mathrm{N}, \mathrm{H}$ ) of The Periphytic Community Attached To Polygonum punctatum Ell. In a Subtropical Reservoir and Its Relationship to Environmental Factors. Limnetica, 32(2), 189 - 200.

Ulqodry T.Z., Yulisman, Syahdan M., Santoso. (2010). Karakteristik Sebaran Nitrat, Fosfat, dan Oksigen Terlarut di Perairan Karimunjawa, Jawa Tengah. Jurnal Penelitian Sains, 13(1), 35-41

Villarreal, J. S., Bernecker, A., Wehrtmann, I. S. (2008). Inventory of Macroalgal Epiphytes on the Seagrass Thalassia testudinum (Hydrocharitaceae) in Parque National Cahuita, Caribbean Coast of Costa Rica. Rev. Biol. Trop, 56(4), 163 - 174.

(C) 2017 by the authors; licensee Udayana University, Indonesia. This article is an open access article distributed under the terms and conditions of the Creative Commons Attribution license (http://creativecommons.org/licenses/by/3.0/). 